\title{
Fusarium Wilt Disease of Banana in India: Current Scenario
}

\section{Siddhesh B Ghag* EDITORIAL}

Department of Rural Technology, Guru Ghasidas Vishwavidyalaya, Bilaspur, 495009, Chhattisgarh, India

Banana (Musa spp.) is one of the most important food crops and is also the staple food of most of the people of the developing regions of the world. The total world production recorded in the year 2016 accounts to approx. 113 million metric ton wherein the production in India was around 29 million metric ton. Edible bananas originated in Asia and then were distributed worldwide. There are more than 100 different varieties of bananas grown in Asia and consumed locally. Most of the edible bananas are triploid formed by inter-specific hybridization of the two diploid originators Musa acuminata Colla (AA genome) and Musa balbisiana Colla (BB genome). The production of bananas in India increased from 14 million metric ton in 2000 to 18 million metric ton in 2005 and then there was a sharp increase to 29 million metric ton in the year 2010. Moreover the area harvested was significantly high from 2005 (569,500 ha) to 2010 ( 830,000 ha). The production of banana is severely affected by diseases such as Fusarium wilt disease, banana bunchy top disease and Sigatoka disease which reduces yield to $100 \%$. Fusarium wilt disease is a fungal disease caused by a soil pathogen Fusarium oxysporum f. sp. cubense (Foc). Foc spores present in the soil or in the infected planting material finds entry through the roots and into the rhizome of the healthy banana plant. Thereby, it travels towards the vascular tissues and blocks it, resulting in wilt symptoms [1,2]. Eventually the infected banana plant dies because of poor water conduction, cell death and toxins released by Foc. Managing Fusarium wilt disease of banana by chemical or physical methods is found to be problematic. Sustainable solution towards controlling Fusarium wilt disease of banana is planting resistant varieties. Gros Michel variety of banana that dominated world market in early $19^{\text {th }}$ century was wiped out by the race 1 strain of Foc. The banana growers and banana industry shifted the cultivation to the race 1 resistant Cavendish varieties that replaced Gros Michel variety. However, in late $20^{\text {th }}$ century another strain of Foc, known as tropical race 4 (TR4), was found infecting Cavendish variety and is now rampantly spreading in the major banana growing regions threatening its production. Beginning of $21^{\text {st }}$ century TR4 was recorded in South Asia, Africa, China and Australia. This problem is constantly looming over the heads of the banana scientist and banana growers to identify a substitute for the Cavendish variety.

In India, Fusarium wilt disease caused by race 1 strain of Foc resulted in yield reduction up to 50\%-70\%. The major varieties affected were Rasthali, Amrithapani, Karpuravalli, Monthan, Ney Poovan, and Virupakshi [3,4]. Amrithapani variety is most sensitive to Fusarium wilt disease and farmers in Andhra Pradesh have abandoned the cultivation for more than 15-20 years from now. Some varieties in India such as the Red banana and Nendran were found to be resistant to race 1 infections. The race structure in Foc is quite indistinct and thus the vegetative compatibility was used to categorize this pathogen. Some vegetatively compatibility groups are cross-compatible and form VCG complexes. In India, VCG 0124 and VCG 0125 has been reported in the banana infected fields. Shifting the cultivation to race 1 resistant cultivars (i.e. resistant to VCG 0124/25 complex) in India lessened the problem but the new variant TR4 is now affecting all the banana varieties cultivated in India. The TR4 VCGs complex 01213/16 was identified infecting Grand Naine varieties in the Bihar state (Katihar and Purnea districts) of India. The pathogen is on a move and have shown its presence infecting Cavendish varieties in Uttar Pradesh (Faizabad district), Madhya Pradesh (Burhanpur district) and Gujarat (Surat district) states [4]. Moreover, TR4 is further spreading to Maharashtra which is of a serious concern now as the major banana hub of India; the Jalgoan district is under threat. Furthermore, since Foc remains in the soil in dormant form, no fresh plantations are possible in the infected field. This will eventually result in shifting cultivation to some other crop or migration of farmers to different regions. Thus, Fusarium wilt disease has become a serious threat to the sustainability of Indian banana growers. After incidence now it is important to contain the spread of this disease by completely quarantining the infected field and preventing the movement and entry and/or exit of any material from the field. The infected plants should be destroyed. Using disease free planting material will prevent the spread of this disease. Creation of awareness and training of farm personnel on the significance of Fusarium wilt disease, its identification, diagnosis and prevention is a pre-requisite to halt further spread of this disease. In long run, the present scenario demands a sustainable solution such as planting of resistant cultivars, *Correspondence to: Siddhesh B Ghag, School of Biological Sciences, UM-DAE Centre for Excellence in Basic Sciences, Kalina campus, Santacruz,
Mumbai-400098, India, Tel: 91-22-26524978; E-mail: siddhesh.ghag@cbs.ac.in

Received date: December 12, 2018; Accepted date: January 02, 2019; Published date: January 21, 2019

Citation: Ghag SB (2019) Fusarium Wilt Disease of Banana in India: Current Scenario. Agrotechnology 8: e121. doi: 10.35248/2168-9881.19.8.e121

Copyright: (C2019 Ghag SB. This is an open-access article distributed under the terms of the Creative Commons Attribution License, which permits unrestricted use, distribution, and reproduction in any medium, provided the original author and source are credited. 
identification of botanicals and antagonist microbes to reduce disease severity.

\section{REFERENCES}

1. Ghag SB, Shekhawat UK, Ganapathi TR. Fusarium wilt of banana: biology, epidemiology and management. Int J Pest Manage. 2015;61:250-263.

2. Dita M, Barquero M, Heck D, Mizubuti ES, Staver CP. Fusarium wilt of banana: Current knowledge on epidemiology and research needs toward sustainable disease management. Front Plant Sci. 2018;9:1468.

3. Thangavelu R, Mustaffa MM. First report on the occurrence of a virulent strain of Fusarium wilt pathogen (Race-1) infecting Cavendish (AAA) group of bananas in India. Plant Dis. 2010;94:1379.

4. Thangavelu R. Status report on fusarium wilt disease in India. ICAR-NRC for Banana Tiruchirapalli, India. 2016;1-85. 